\title{
Study of Genetic Variation among Some Wild Landraces of Zingiber officinale Roscoe Correlated with Their Antioxidant Potential Status
}

\author{
Subhabrata Ghosh \\ Bose Institute, 93/1 A. P. C Road, Kolkata 700009, India \\ Swati Sen Mandi (Corresponding author) \\ Bose Institute, 93/1 A. P. C Road, Kolkata 700009, India \\ Tel: 91-332-303-1125 E-mail: senmandi.swati@gmail.com
}

Received: November 16, 2011

Accepted: November 28, $2011 \quad$ Published: December 31, 2011

doi:10.5539/jmbr.v1n1p77

URL: http://dx.doi.org/10.5539/jmbr.v1n1p77

The authors are grateful to Indian Council of Medical Research (ICMR) for providing fund in the project

"Centre for Advanced Research in DNA fingerprinting and diagnostics of medicinal potential in plants from Eastern and North Eastern India" operative at Bose Institute, Kolkata. One of the authors (Subhabrata Ghosh) is grateful to ICMR for an adhoc Senior Research fellowship

\begin{abstract}
DNA fingerprinting based genotype characterization and assessment of genetic diversity of fifteen wild landraces of Zingiber officinale. Roscoe, collected from different parts of northern West Bengal, India, has been done using 16 random decamer primers. Out of 117 amplified products, 97 bands showed polymorphism $(82.90 \%)$ and an average of 7.5 bands was amplified per primer. The genetic similarity coefficients among accessions ranged from 0.673 to 0.912 with an average of 0.792 . Cluster analysis based on Jaccard's similarity coefficient using UPGMA grouped the landraces into three clusters: cluster I consisting of 5 landraces, Cluster II consisting of 6 landraces, and cluster III of 4 landraces; Antioxidant potential status of these genotypes exhibit variation that shows grouping comparable with the RAPD based dendogram (reflecting genetic relatedness) of the landraces.
\end{abstract}

Keywords: Zingiber officinale Roscoe, DNA fingerprinting, RAPD, Antioxidant potential, Trait related clustering

\section{Introduction}

Ginger plants have known to have originated in South East Asia, probably in India (Burkill, 1990; Purseglove et al., 1981). One of the species under this group viz. Zingiber officinale that is known to possess markedly high antioxidant potential compared to other species studied till date (compare with Zingiber kawagoii, Zingiber oligophyllum-- Nan-Chen et al., 2008), is cultivated in several countries such as in Australia, Bangladesh, Haiti, Jamaica, Japan, Nigeria, Sri-Lanka, and South East Asian countries including China, Nepal, Malaysia, North Korea, Sri-Lanka, Thailand, Japan, Bangladesh, Indonesia and India (Wu and Larsen, 2000). In addition to availability under cultivation, large populations of these plants are also available as land races in the wild, with Eastern and North-Eastern India, one of the biodiversity hot spots of the world, being home to its several of the genotypes. Rhizomes of the plants are used as spice whereas both rhizomes and leaves provide important source of medicine. Several landraces of Zingiber officinale have been identified by local communities to be elite with respect to medicinal and spice value (Sanjeev et al.,2011). Some of genotypes of Zingiber officinale are particularly valued for their non-fibrous rhizomes that are likely to provide high content of biomolecules in the higher content of soft tissue (Kizhakkajii and Sasikumar, 2011). Being vegetatively propagated by rhizomes that constitute the plant part for spices and medicines, such plants run the risk of overexploitation in the wild, this adds to the urgent need for Documentation Evaluation and Conservation of these plants. Understanding genome profiling vis-à-vis antioxidant (medicinal) potential of wild population of ginger plants for screening hitherto 
unexplored medicinal plants that would help to bring underutilized germplasm to cultivation focus, would repay careful investigation.

Use of precise parameters, not varying with variation in environment/ stage of life cycle, viz. DNA profiling constitute the modern method of choice for authentic characterization of plants in general, and for Zingiberaceae (where flowering is not a regular phenomenon) in particular. Plant DNA analysis also allows precise understanding of phylogenetic relationships between plants (Williams et al., 1990, Paterson et al., 1991) and is considered the ultimate in plant taxonomy. Chemical analysis for medicinal potential correlated with DNA fingerprinting patterns and associated phylogenetic relationship study between the different groups could also provide information on variation in antioxidant (medicinal) potential among the different wild landraces.

The major medicinally active constituents in rhizomes of Zingiber officinale are flavonoids, present as pungent vanilloids, [6]-gingerol and [6]-paradol; these make a significant contribution towards medicinal applications with high antioxidant activity (Chen et al., 1986; Herrmann, 1994). The antioxidant activity of Zingiber officinale has been shown to be effective in lowering lipid peroxidation by maintaining the activities of the antioxidant enzymes--Superoxide dismutase, Catalase and Glutathione Peroxidase in blood (Ahmed et al., 2000).

The RAPD method of DNA profiling reported for identification, phylogenetic analysis, population studies and genetic linkage mapping of many plant species (Williams et al., 1990) constitutes an early method used in DNA analysis. Establishing multilocus markers RAPD analysis of genomes (Karp et el., 1997) provides a versatile and rapid technology requiring low infrastructural input and use of arbitrary primers for developing plant DNA fingerprinting patterns that is useful in a) authentication of wide populations of closely related genotypes (Wilde et al., 1992; Koller et al., 1993; Wolff and Peters-Van Run, 1993; Ahmad, 1999; Simioniue et al., 2002; Lakhanpaul et al., 2000; Chakraborty et al., 2006; Ray Choudhury et al.,2001; Cao et al.,2000; Pejic et al.,1998) and b) in the study of the genetic variability of species or natural populations (Lashermes et al., 1993, Wilkie et al., 1993, Sanatombi et al.,2010; Nayak et al.,2003; Cerqueira et al.,2010; Karatas and Ağaoğlu, 2010). Such studies should help in a) Documentation of medicinal plant genetic resources and b) bringing about precision in drug assessment for preparation of herbal medicines. RAPD markers have been used to evaluate the genetic diversity of other species of Zingiber genus (Saowaluck and Yingyong, 2010-Zingiber montanum and Mohanty et al., 2011 -Zingiber rubens)

Here, we report the use of RAPD fingerprinting technique using 16 random decamer primers for characterizing fifteen Zingiber officinale. Roscoe germplasm collected from different parts of northern districts of West Bengal state of India and estimating the genetic distances and relationships among these genotypes. In parallel we have also studied the antioxidant potential i.e the medicinal value with the dendogram obtained by RAPD analysis to study trait related clustering in correlation with genome profiles.

\section{Materials and Methods}

\subsection{Plant material}

A total of 15 landraces (Rhizome) of Zingiber officinale Roscoe germplasm were collected from Uttar Banga Krishi Vishwavidyalaya (UBKV) Coochbehar, West Bengal, India. These landraces are collected from different northern districts of West Bengal, viz. Jalpaiguri, Coochbehar, Darjeeling, North Dinajpur (Table 1). They were collected in the month of May-2008. Voucher specimens of all the samples are preserved at Central National Herbarium (CAL), Botanical Survey of India, Howrah for future reference.

\subsection{DNA extraction}

DNA was extracted from fresh leaves of 3 months old plants by the $2 \%$ CTAB method (Bousquet et al., 1990). Approximately, $200 \mathrm{mg}$ of fresh leaf were ground to a powder in liquid nitrogen, using a mortar and pestle. The powder was transferred to a $25 \mathrm{ml}$ sterile Falcon tube with $10 \mathrm{ml}$ of CTAB buffer. The extraction buffer consisted of $2 \%$ (w/v) CTAB (cetyltrimethyl ammonium bromide, Sigma), $1.4 \mathrm{M} \mathrm{NaCl}, 20 \mathrm{mM}$ EDTA, $100 \mathrm{mM}$ Tris- $\mathrm{HCl} \mathrm{pH} \mathrm{8.0,} \mathrm{and} 0.2 \%(\mathrm{v} / \mathrm{v}) \beta$-mercaptoethanol. The homogenate was incubated at $65^{\circ} \mathrm{C}$ for $1 \mathrm{~h}$, extracted with an equal volume of chloroform, and centrifuged at $10,000 \mathrm{rpm}$ for $20 \mathrm{~min}$. DNA was precipitated from the aqueous phase by mixing with $1 / 10$ volume $(\mathrm{ml})$ of $3 \mathrm{M}$ sodium acetate and an equal volume of isopropanol. After centrifugation at 10,000 rpm for $10 \mathrm{~min}$, the DNA pellet was washed with $70 \%$ ethanol; air dried, and resuspended in $10 \mathrm{mM}$ Tris $\mathrm{pH} 8.0,0.1 \mathrm{mM}$ EDTA buffers. The concentration of DNA in the samples was determined by calculation from 260/280 O.D value. The DNA samples are subjected to electrophoresis on $0.8 \%$ agarose gel; genomic $\lambda$ DNA $(25 \mathrm{ng} / \mu \mathrm{l})$ was used as molecular weight standard. All DNA samples taken for RAPD study showed 260 O.D/280 O.D value between 1.75-2.00. 


\subsection{RAPD amplification}

Sixteen arbitrary 10-base primers (Operon Technologies Inc) were used for polymerase chain reaction (PCR), following the protocol of Williams et al (1990), with minor modifications. Each PCR reaction was performed in a total volume of $25 \mu 1$ containing $10 \mathrm{X}$ PCR buffer, $0.3 \mathrm{mM} \mathrm{MgCl} 2,0.1 \mathrm{mM}$ dNTPs $(0.025 \mathrm{mM}$ each dNTP), 1.8 $\mathrm{ng} / \mathrm{ml}$ decamer primer (Operon), $0.04 \mathrm{U} / \mathrm{ml}$ Taq DNA polymerase (New England Biolab) and 25ng of genomic DNA. The PCR amplification reaction consisted of an initial denaturation at $94{ }^{\circ} \mathrm{C}$ for 2 min followed by 45 cycles, each consisting of denaturation at $94^{\circ} \mathrm{C}$ for $1 \mathrm{~min}$, annealing at $36^{\circ} \mathrm{C}$ for $1 \mathrm{~min}$ and extension at $72^{\circ} \mathrm{C}$ for 2 min. It was followed by a final extension at $72^{\circ} \mathrm{C}$ for $10 \mathrm{~min}$. As RAPD method is to some extent has low reproducibility, we have repeated each RAPD PCR reaction three times and observed similar banding pattern each time. The PCR products were separated by gel electrophoresis in a $1.5 \%$ agarose gel containing ethidium bromide in 1x TBE buffer and $1 \mathrm{~Kb}$ ladder and 100bp ladder (New England Biolab) was run along with the samples to determine the molecular sizes of the fragments. Gels were photographed in a UV transillumunator of a Gel-documentation System (Biorad).

\subsection{Scoring and data analysis}

Amplified DNA markers were scored as present or absent in each plant. Electrophoretic DNA bands of low visual intensity that could not be readily distinguished as present or absent were considered ambiguous markers and were not scored. For diversity analysis, bands were scored as present (1) or absent (0) to form a raw data matrix. Genetic distance was calculated by Jaccard's coefficient (Jaccard 1908), which is as follows: $\mathrm{S}_{\mathrm{ij}}=\mathrm{N}_{\mathrm{ij}} /\left(\mathrm{N}_{\mathrm{ii}}+\mathrm{N}_{\mathrm{ij}}+\mathrm{N}_{\mathrm{jj}}\right)$ where $\mathrm{S}_{\mathrm{ij}}$ is the similarity index between the ith and jth genotype, $\mathrm{N}_{\mathrm{ij}}$ is the number of bands present in both genotype, $\mathrm{N}_{\mathrm{ii}}$ is the number of bands present in the ith genotype but absent in the jth genotype, and $\mathrm{N}_{\mathrm{jj}}$ is the number of bands absent in the ith genotype and present in the jth genotype. The average similarity matrix was used to generate a tree for cluster analysis by UPGMA (Unweighted Pair Group Method with Arithmetic mean) method using NTSys v 2.1.

\subsection{Total antioxidant potential assay}

It is well known that the antioxidant activity of plant extracts containing polyphenol components is due to their capacity to be donors of hydrogen atoms or electrons and to capture the free radicals. DPPH analysis (Shimada et $a l ., 1992)$ is one of the tests used to prove the ability of the components of the ginger extract to act as donors of hydrogen atoms. For estimation of Total antioxidant potential of Zingiber officinale landraces, $100 \mathrm{mg}$ of fresh rhizome sample was taken and $5 \mathrm{ml}$ of freshly prepared $90 \%$ methanol was added to it. Then after keeping in room temperature for 1 hour with intermittent shaking, $100 \mu \mathrm{l}$ from this solution was taken and $1 \mathrm{ml}$ of $0.004 \%$ 1,1-Diphenyl-2-picrylhydrazyl (DPPH) was added to it. After keeping in dark for 30 minutes, the reduction of the DPPH free radical was measured by reading the absorbance at $517 \mathrm{~nm}$. DPPH, a purple-colored, stable free radical is reduced to the yellow-colored diphenylpicrylhydrazine when antioxidants are added. All samples were analyzed in triplicates. $90 \%$ Methanol was used as control. The inhibition ratio (percent) was from the equation:

$$
\% \text { inhibition }=\frac{\left(\mathrm{A}_{\text {control }}-\mathrm{A}_{\text {sample }}\right) \times 100 \%}{\mathrm{~A}_{\text {control }}}
$$

Where $\mathrm{A}_{\text {control }}$ is the absorbance of the control at $\mathrm{t}=0 \mathrm{~min}$ and $\mathrm{A}_{\text {sample }}$ is the absorbance of the sample at $\mathrm{t}=30$ minutes. The antioxidant activity of each sample was expressed in terms of EC50 (the concentration required to inhibit DPPH radical formation by $50 \%$ ).

\section{Results}

Sixteen decamer primers were used for the PCR reactions and all the sixteen primers could detect polymorphism significantly in the genomic DNA through RAPD analysis (Figure $1 \&$ Figure 2). The primer names and the data on the number of polymorphic bands obtained are given (Table 2).Out of total 117 bands scored from the sixteen primers, 97 were found to be polymorphic and only 20 were found to be monomorphic bands. The binary data scored from all the sixteen primers were used for the calculation of Jaccard's similarity index (Table 3). In the dendogram (Figure 3) three clusters were observed. Cluster I contains five genotypes (GCP-18, G-05-07, G-03-05, G-23-05,PGS-08 ) , cluster II contains six genotypes (GCP-16,G-04-07,GCP-08, GCP-27,GCP-05, IG-1) and cluster III contain four (GCP-29,GCP-22,G-01-07,GCP-44) genotypes. The extent of genetic relatedness among Zingiber officinale Roscoe genotypes varied considerably (0.703 to 0.912$)$. Highest similarity (0.989) was observed in G-04-07 and GCP-27.Few more pairs viz. PGS-08 and G-23-05; G-03-05 and GCP-18; were also found to show high degree of commonness. Least genetic similarity $(0.703)$ was obtained between GCP-16 and G-01-07.This similarity index (Table 3) helped us to evaluate the genetic relatedness and also the 
genetic variation of the different landraces of Zingiber officinale, collected from different areas of Northern part of West Bengal, India.

The results obtained from the analysis of total antioxidant activity of Zingiber officinale landraces by DPPH method are shown in Table 4. According to the data obtained, significant differences were observed among different landraces for antioxidant activities. Some landraces(viz.GCP-18,G-05-07, G-03-05,G-23-05,PGS-08)have high antioxidant potential, some landraces(GCP-29,GCP-22,G-01-07,GCP-44,) have low antioxidant potential in comparison, and some landraces (GCP-16,G-04-07,GCP-08, GCP-27,GCP-05, IG-1) have intermediate value.

\section{Discussion}

The binary data scored from the RAPD analysis through NTSYS software allowed the development of a dendogram revealing the genetic distance between these genotypes. In the dendogram, three clusters were observed which is correlated with total antioxidant potential of the landraces under study. In the first cluster (Cluster-I) five genotypes had been observed which possess high antioxidant potential in comparison to other genotypes. Another cluster (Cluster-II) that consisted of six genotypes had antioxidant potential values that appear intermediate between the two extreme groups. In the third cluster (Cluster-III), four genotypes were located which possess low antioxidant value.

For genetic diversity analysis of 46 Zingiber officinale accessions from different countries including different places of India using RAPD and ISSR method has been reported by Kizhalkayil and Sasikumar (2010). In another study of RAPD analysis of Zingiber officinale by Rout et al. (1998), RAPD markers were used to evaluate the genetic stability of micropropagated plants of Zingiber officinale. Fifteen primers were used to amplify DNA from in vivo and in vitro plant material to assess the genetic fidelity. All RAPD profiles from micropropagated plants were monomorphic and similar to those of field grown control plants. No variation was detected within the micropropagated plants. Palai and Rout (2007) also reported RAPD analysis using twelve primers for identification and analysis of genetic variation within eight high yielding (cultivated) varieties of ginger for evaluating genetic relationship among them. Genetic diversity of other species of the genus Zingiber have also been studied (Saowaluck and Yingyong, 2010-Zingiber montanum and Mohanty et al., 2011 -Zingiber rubens).

Nan-Chen et al. (2008) evaluated antioxidant potential of some species of Zingiber genus viz, Zingiber kawagoii and Zingiber oligophyllum in Taiwan where values are found to be as low as $42 \%$ and $32 \%$ respectively. Stoilova et al. (2007) have used air-dried roots of Zingiber officinale from Vietnam. The methods they have used for determination of antioxidant potential are DPPH assay, linolenic acid model system, deoxyribose assay. In their study the Zingiber officinale varieties have showed upto 91\% antioxidant activity in DPPH assay. Maizura et al. (2011) reported antioxidant value of Zingiber officinale in Malaysia to be $79 \%$. In another study on cultivated varieties of Zingiber officinale of India by Shirin and Jamuna (2010), antioxidant potential was shown to be $80 \%$.

In our present study, we have performed RAPD analysis of fifteen landraces of Zingiber officinale Roscoe, collected from different areas of Northern part of West Bengal, India, using 16 random primers. Antioxidant assay of these landraces have been done using DPPH method. In the dendogram, obtained after RAPD analysis, clustering of genotypes can be correlated with their antioxidant potential. This is the first report in Zingiber officinale where such correlation has been established.

\section{Acknowledgements}

The authors are grateful to Indian Council of Medical Research (ICMR) for providing fund in the project "Centre for Advanced Research in DNA fingerprinting and diagnostics of medicinal potential in plants from Eastern and North Eastern India" operative at Bose Institute, Kolkata. One of the authors (Subhabrata Ghosh) is grateful to ICMR for an adhoc Senior Research fellowship. Authors wish to thank Director, Botanical Survey of India (BSI) for herbarium support. The authors also wish to thank Prof. B.C. Saha \& Dr Sekhar Bandhopadhyay, Uttar Banga Krishi Vishwavidyalaya (UBKV), for providing the experimental Zingiber officinale Roscoe plant materials.

\section{References}

Ahmad, F. (1999). Random amplified polymorphic DNA (RAPD) analysis reveals genetic relationships among the annual Cicer species. Theor. Appl. Genet, 98, 657-663. http://dx.doi.org/10.1007/s001220051117 
Ahmed, R. S., Seth, V., \& Banerjee, B. D. (2000). Influence of dietary ginger (Zingiber officinales Rosc) on antioxidant defense system in rat: comparison with ascorbic acid. Indian $J$ Exp Biol, 38(6), 604-606. http://www.ncbi.nlm.nih.gov/pubmed/11116533

Bousquet, J., Simon, L., \& Lalonde, M. (1990). DNA amplification from vegetative and sexual tissues of trees using polymerase chain reaction. Can. J. For. Res, 20, 254, 457.

Bua-in S., \& Paisooksantivatana, Y. (2010). Study of clonally propagated cassumunar ginger (Zingiber montanum (Koenig) Link ex Dietr.) and its relation of wild Zingiber species from Thailand revealed by RAPD markers. Genetic Resources and Crop Evolution, 57(3), 405-414. http://dx.doi.org/10.1007/s10722-009-9479-2

Burkill, I. H. (1966). A Dictionary of the Economic Products of the Malay Peninsula,Kuala Lumpur, Ministry of Agriculture and Co-operatives.

Cao, W., Scoles, G., Hucl, P., \& Chibbar, R. N. (2000). Phylogenetic relationships of five morphological groups of hexaploid wheat (Triticum aestivum L. em Thell.) based on RAPD analysis. Genome, 43, 724-727.

Cerqueira-Silva, C. B. M., Conceição, L. D. H. C. S., Santos, E. S. L., et al. (2010). Genetic variability in wild genotypes of Passiflora cincinnata based on RAPD markers. Genetics and Molecular Research, 9(4), 2421-2428. http://dx.doi.org/10.4238/vol9-4gmr981

Chakrabarti, S. K., Pattanayak, D., Sarkar, D., Chimote, V. P., \& Naik, P. S. (2006). Stability of RAPD fingerprints in potato: effect of source tissue and primers. Biol. Plant, 50, 531-536. http://dx.doi.org/10.1007/s10535-006-0084-3

Chen, Ch., Kuo, M., Wu, Ch., \& Ho, Ch. (1986). Pungent compounds of ginger (Zingiber officinale (L) Rosc) extracted by liquid carbon dioxide. Journal of Agricultural and Food Chemistry, 34, 477-480. http://dx.doi.org/10.1021/jf00069a027

Herrmann, K. (1994). Antioxidativ wiksame Pflanzenphenole sowie Carotinoide als wichtige Inhaltsstoffe von Gewürzen. Gordian, 94, 113-117.

Jaccard, P. (1908). Nouvelles researches sur la distribution florale. Bull. Soc. Vaudoise Sci. Natl, 44, 223-270.

Karataş, H., \& Ağaoğlu,Y. S. (2010). RAPD analysis of selected local Turkish grape cultivars (Vitis vinifera). Genetics and Molecular Research, 9 (4), 1980-1986. http://dx.doi.org/10.4238/vol9-4gmr926

Karp, A., Kresovich, S., Bhat, K., Ayad, W., \& Hodgkin, T. (1997). Molecular tools in plant genetic resources conservation: a guide to the technologies. IPGRI. Rome, Italy.

Kizhakkayil, J. \& Sasikumar, B. (2010). Genetic diversity analysis of ginger (Zingiber officinale Rosc.) germplasm based on RAPD and ISSR markers. Scientia horticulturae, 125(1), 73-76.

Kizhakkayil, J., \& Sasikumar, B. (2011). Diversity, characterization and utilization of ginger: a review. Plant Genetic Resources, 9, 464-477. http://dx.doi.org/10.1017/S1479262111000670

Koller, B., Lehmann, A., Mcdermott, J. M., \& Gessler, C. (1993). Identification of apple cultivars using RAPD markers. Theor Appl Genet, 85, 901-904. http://dx.doi.org/10.1007/BF00225036

Lakhanpaul, S., Chadha, S., \& Bhat, K. V. (2000). Random amplified polymorphic DNA (RAPD) analysis in Indian mung bean (Vigna radiata (L.) Wilczek) cultivars. Genetica, 109, 227-234. http://dx.doi.org/10.1023/A:1017511918528

Lashermes, P.H., Cros, J., Marmey, P. H., \& Charrier, A. (1993). Use of random amplified polymorphic DNA markers to analyze genetic variability and relationships of Coffea species. Crop Evolution Genetic Resource, 40, 91-99.

Maizura, M., Aminah, A., \& Wanaida, W. M. (2011). Total phenolic content and antioxidant activity of kesum (Polygonum minus), ginger (Zingiber officinale) and turmeric (Curcuma longa) extract. International Food Research Journal, 18, 529-534.

Mohanty, S., Panda, M. K., Sahoo, S., \& Nayak, S. (2011). Micropropagation of Zingiber rubens and assessment of genetic stability through RAPD and ISSR markers. Biologia Plantarum, 55(1), 16-20. http://dx.doi.org/10.1007/s10535-011-0002-1

Nan Chen,I., Chen-Chin, C., Chang-Chai, N., Chung-Yi, W., Yuan-Tay, S., \& Tsu-Liang, Chang. (2008). Antioxidant and Antimicrobial Activity of Zingiberaceae Plants in Taiwan. Plant Foods Hum Nutr, 63, 15-20.

Nayak, S., Rout, G. R., \& Das, P. (2003). Evaluation of the genetic variability in bamboo using RAPD markers. Plant Soil Environ, 49(1), 24-28. 
Palai, S. K., \& Rout. G. R. (2007). Identification and genetic variation among eight varieties of ginger by using random amplified polymorphic DNA markers. Plant Biotechnology, 24, 417-420. http://dx.doi.org/10.5511/plantbiotechnology.24.417

Paterson, A H., Tanksley, S. D., \& Sorreis, M.E. (1991). DNA markers in plant improvement. Adv Agronomy, 46, 39-90. http://dx.doi.org/10.1016/S0065-2113(08)60578-7

Pejic, I., Ajmone-Marson, P., Morgante, M., et al. (1998). Comparative analysis of genetic similarity among maize inbred lines detected by RFLPs, RAPDs, SSRs and AFLPs. Theor.Appl. Genet, 97, 1248-1255. http://dx.doi.org/10.1007/s001220051017

Purseglove, J. W., Brown, E. G., Green, C. L. \& Robbins, S. R. J. (1981). Spices Vol.2.Longman Inc. New York. Ray Choudhury, P., Kohli, S., Srinivasan, K., Mohapatra, T., \& Sharma, R. P. (2001). Identification and classification of aromatic rices based on DNA fingerprinting. Euphytica, 118, 243-251. http://dx.doi.org/10.1023/A:1017554600145

Rout, G. R., Das, P., Goel, S., \& Raina, S. N. (1998). Determination of genetic stability of micropropagated plants of ginger using Random Amplified Polymorphic DNA (RAPD)markers. Bot. Bull. Acad. Sin, 39, 23.27.

Sajeev, S., Roy, A. R., Iangrai, B., Pattanayak, A., \& Deka, B. C. (2011). Genetic diversity analysis in the traditional and improved ginger (Zingiber officinale Rosc.) clones cultivated in North-East India. Scientia Horticulturae, 128(3), 3182-188. http://dx.doi.org/10.1016/j.scienta.2011.01.024

Sanatombi, K., SenMandi, S., \& Sharma, G. J. (2010). DNA profiling of Capsicum landraces of Manipur. Scientia Horticulturae, 124, 405-408. http://dx.doi.org/10.1016/j.scienta.2010.01.006

Shimada, K., Fujikawa, K., Yahara, K., \& Nakamura, T. (1992). Antioxidative properties of xanthan on the autooxidation of soybean oil in cyclodextrin. $J$ Agric Food Chem, 40, 945-948. http://dx.doi.org/10.1021/jf00018a005

ShirinAdel P. R., \& Prakash, J. (2010). Chemical composition and antioxidant properties of ginger root (Zingiber officinale). Journal of Medicinal Plants Research, 4(24), 2674-2679.

Simioniuc, D., Uptmoor, R., Friedt, W., \& Ordon, F. (2002). Genetic diversity and relationships among pea cultivars revealed by RAPDs and AFLPs. Plant Breed, 121, 429-435. http://dx.doi.org/10.1046/j.1439-0523.2002.733320.x

Stoilova, I., Krastanov, A., Stoyanova, A., Denev, P., \& Gargova, S. (2007). Antioxidant activity of a ginger extract (Zingiber officinale) Food Chemistry, 102, 764-770. http://dx.doi.org/10.1016/j.foodchem.2006.06.023

Wilde, J., Waugh, R., \& Powell, W. (1992). Genetic finger printing of Theobroma clones using randomly amplified polymorphic DNA markers. Theor Appl Genet, 83, 871-877. http://dx.doi.org/10.1007/BF00226710

Wilkie, S. E., Isaac, P. G., \& Slater, R. J. (1993). Random amplified polymorphic DNA (RAPD) markers for genetic analysis in Allium. Theor Appl Genet, 86, 497-504. http://dx.doi.org/10.1007/BF00838566

Williams, J. G. K., Kubelik, A. R., Livak, K. J., Rafalski, J. A., \& Tingey, S. V. (1990). DNA polymorphism amplified by arbitrary primers are useful as genetic markers. Nucl. Acid. Res, 18, 6531-6535. http://dx.doi.org/10.1093/nar/18.22.6531

Wolff, K., \& Peters-Van Run, J. (1993). Rapid detection of genetic variability in Chrysanthemum (Dendranthema grandiflora Tzvelev.) using random primers. Heredity, 71, 335-341. http://dx.doi.org/10.1038/hdy.1993.147

Wu, T. L., \& Larsen, K. (2000). Zingiberaceae. Flora of China, 24, 322-377. 
Table 1. Scientific name, Family, GPS Data, Place \& Date of collection of the experimental Zingiber officinale Roscoe germplasm

\begin{tabular}{|c|c|c|c|c|c|}
\hline $\begin{array}{l}\text { Sl } \\
\text { No }\end{array}$ & $\begin{array}{l}\text { Accession No. } \\
\text { of the plants }\end{array}$ & Scientific name & Family & $\begin{array}{c}\text { Latitude, } \\
\text { Longitude \& } \\
\text { Elevation }(\mathrm{m})\end{array}$ & $\begin{array}{l}\text { Place \& Date } \\
\text { of Collection }\end{array}$ \\
\hline 1 & G-04-07 & Zingiber officinale & Zingiberaceae & $\begin{array}{c}26^{\circ} 22^{\prime} \mathrm{N} \\
89^{\circ} 29^{\prime} \mathrm{E} \\
45 \mathrm{~m}\end{array}$ & $\begin{array}{c}\text { Kamat Abutara } \\
\text { Coochbehar } \\
\text { West Bengal } \\
20.03 .2008\end{array}$ \\
\hline 2 & G-23-05 & Zingiber officinale & Zingiberaceae & $\begin{array}{c}26^{\circ} 32^{\prime} \mathrm{N} \\
88^{\circ} 46^{\prime} \mathrm{E} \\
75 \mathrm{~m}\end{array}$ & $\begin{array}{c}\text { Uttar Balaguri, } \\
\text { Dist-Jalpaiguri, } \\
\text { West Bengal } \\
20.03 .2008\end{array}$ \\
\hline 3 & GCP-08 & Zingiber officinale & Zingiberaceae & $\begin{array}{c}26^{\circ} 22^{\prime} \mathrm{N} \\
89^{\circ} 29^{\prime} \mathrm{E} \\
45 \mathrm{~m}\end{array}$ & $\begin{array}{c}\text { Tufanganj Bazar, } \\
\text { Coochbehr, } \\
\text { West Bengal. } \\
\text { 20.03.2008 }\end{array}$ \\
\hline 4 & PGS-08 & Zingiber officinale & Zingiberaceae & $\begin{array}{l}26^{\circ} 32^{\prime} \mathrm{N} \\
88^{\circ} 46^{\prime} \mathrm{E} \\
75 \mathrm{~m}\end{array}$ & $\begin{array}{c}\text { Birpara market } \\
\text { Dist-Jalpaiguri, } \\
\text { West Bengal } \\
20.03 .2008 \\
\end{array}$ \\
\hline 5 & G-01-07 & Zingiber officinale & Zingiberaceae & $\begin{array}{c}25^{\circ} 56^{\prime} \mathrm{N} \\
87^{\circ} 58^{\prime} \mathrm{E} \\
53 \mathrm{~m}\end{array}$ & $\begin{array}{c}\text { North Dinajpur Dist,Old } \\
\text { Alluvial zone,West Bengal } \\
20.03 .2008 \\
\end{array}$ \\
\hline 6 & GCP-29 & Zingiber officinale & Zingiberaceae & $\begin{array}{c}26^{\circ} 32^{\prime} \mathrm{N} \\
88^{\circ} 46^{\prime} \mathrm{E} \\
3031 \mathrm{~m} \\
\end{array}$ & $\begin{array}{c}\text { Pattangi, Orissa } \\
20.03 .2008\end{array}$ \\
\hline 7 & G-05-07 & Zingiber officinale & Zingiberaceae & $\begin{array}{c}26^{\circ} 32^{\prime} \mathrm{N} \\
88^{\circ} 46^{\prime} \mathrm{E} \\
75 \mathrm{~m}\end{array}$ & $\begin{array}{c}\text { Madarihat locality } \\
\text { (Before Birpara) } \\
\text { Dist-Jalpaiguri, } \\
\text { West Bengal } \\
\text { 20.03.2008 }\end{array}$ \\
\hline 8 & GCP-22 & Zingiber officinale & Zingiberaceae & $\begin{array}{l}18^{\circ} 56^{\prime} \mathrm{N} \\
82^{\circ} 96^{\prime} \mathrm{E} \\
30 \mathrm{~m}\end{array}$ & $\begin{array}{c}\text { Nijamatpur, Gopalpukur- } \\
\text { Dist. North Dinajpur } \\
\text { West Bengal }\end{array}$ \\
\hline 9 & GCP-05 & Zingiber officinale & Zingiberaceae & $\begin{array}{l}27^{\circ} 03^{\prime} \mathrm{N} \\
88^{\circ} 18^{\prime} \mathrm{E} \\
2250 \mathrm{~m}\end{array}$ & $\begin{array}{c}\text { Jambari south,Gosanimari, } \\
\text { Coochbehar } \\
\text { West Bengal } \\
20.03 .2008\end{array}$ \\
\hline 10 & GCP-27 & Zingiber officinale & Zingiberaceae & $\begin{array}{l}26^{\circ} 22^{\prime} \mathrm{N} \\
89^{\circ} 29^{\prime} \mathrm{E} \\
45 \mathrm{~m}\end{array}$ & $\begin{array}{c}\text { Jambari south,Gosanimari, } \\
\text { Coochbehar } \\
\text { West Bengal } \\
20.03 .2008\end{array}$ \\
\hline 11 & G-03-05 & Zingiber officinale & Zingiberaceae & $\begin{array}{c}26^{\circ} 32^{\prime} \mathrm{N} \\
88^{\circ} 46^{\prime} \mathrm{E} \\
75 \mathrm{~m}\end{array}$ & $\begin{array}{c}\text { Odlabari } \\
\text { Dist-Jalpaiguri, } \\
\text { West Bengal } \\
20.03 .2008\end{array}$ \\
\hline 12 & IG-1 & Zingiber officinale & Zingiberaceae & $\begin{array}{l}26^{\circ} 32^{\prime} \mathrm{N} \\
88^{\circ} 46^{\prime} \mathrm{E}\end{array}$ & $\begin{array}{c}\text { Gorubathan } \\
\text { Dist-Darjeeling }\end{array}$ \\
\hline
\end{tabular}




\begin{tabular}{|c|c|c|c|c|c|}
\hline & & & & $2250 \mathrm{~m}$ & $\begin{array}{c}\text { West Bengal } \\
20.03 .2008\end{array}$ \\
\hline 13 & GCP-18 & Zingiber officinale & Zingiberaceae & $\begin{array}{c}26^{\circ} 32^{\prime} \mathrm{N} \\
88^{\circ} 46^{\prime} \mathrm{E} \\
75 \mathrm{~m}\end{array}$ & $\begin{array}{l}\text { Uttar Madarihat } \\
\text { Dist-Jalpaiguri, } \\
\text { West Bengal } \\
\text { 20.03.2008 }\end{array}$ \\
\hline 14 & GCP-44 & Zingiber officinale & Zingiberaceae & $\begin{array}{c}21.90^{\circ} \mathrm{N} \\
83.40^{\circ} \mathrm{E} \\
30 \mathrm{~m}\end{array}$ & $\begin{array}{c}\text { Nijamatpur, Gopalpukur-I, } \\
\text { Dist. North Dinajpur } \\
\text { West bengal } \\
20.03 .2008\end{array}$ \\
\hline 15 & GCP-16 & Zingiber officinale & Zingiberaceae & $\begin{array}{c}26^{\circ} 22^{\prime} \mathrm{N} \\
89^{\circ} 29^{\prime} \mathrm{E} \\
45 \mathrm{~m}\end{array}$ & $\begin{array}{c}\text { Chawarah Hathkhola } \\
\text { Dinhata } \\
\text { Coochbehar } \\
\text { West Bengal } \\
\text { 20.03.2008 }\end{array}$ \\
\hline
\end{tabular}

Table 2. Primers used for the RAPD analysis (Name and Sequence).Their number and type of bands of fifteen landraces of Zingiber officinale landraces, collected from different areas of eastern India

\begin{tabular}{|c|c|c|c|c|c|}
\hline Primer Name & $\begin{array}{c}\text { Primer Sequence } \\
\qquad\left(5^{\prime}-3^{\prime}\right)\end{array}$ & $\begin{array}{l}\text { No. of Total } \\
\text { bands }\end{array}$ & $\begin{array}{c}\text { No. of } \\
\text { polymorphic } \\
\text { bands }\end{array}$ & $\begin{array}{c}\text { No. of } \\
\text { monomorphic } \\
\text { bands }\end{array}$ & $\begin{array}{c}\text { Percent of } \\
\text { Polymorphism }\end{array}$ \\
\hline OPAA-14 & 5'AACGGGCCAA3' & 12 & 11 & 01 & 0.916 \\
\hline OPAA-16 & 5'GGAACCCACA3' & 14 & 11 & 03 & 0.785 \\
\hline OPAB-06 & 5'GTGGCTTGGA3' & 11 & 08 & 03 & 0.727 \\
\hline OPAC-10 & 5'AGCAGCGAGG3' & 10 & 09 & 01 & 0.900 \\
\hline OPAG-13 & 5'GGCTTGGCGA3' & 17 & 15 & 02 & 0.882 \\
\hline OPAH-12 & 5'TCCAACGGCT3' & 15 & 12 & 03 & 0.800 \\
\hline OPAI-05 & 5'GTCGTAGCGG3' & 10 & 08 & 02 & 0.800 \\
\hline OPAL-04 & 5'ACAACGGTCC3' & 14 & 13 & 01 & 0.928 \\
\hline OPAL-13 & 5'GAATGGCACC3' & 13 & 11 & 02 & 0.846 \\
\hline OPBC-13 & 5'CCTGGCACAG3' & 14 & 13 & 01 & 0.928 \\
\hline OPBE-10 & 5'AAGCGGCCCT3' & 10 & 08 & 02 & 0.800 \\
\hline OPBH-01 & 5'CCGACTCTGG3' & 13 & 12 & 01 & 0.923 \\
\hline OPBH-06 & 5'TCGTGGCACA3' & 13 & 10 & 03 & 0.769 \\
\hline OPE-18 & 5'GGACTGCAGA3' & 15 & 12 & 03 & 0.800 \\
\hline OPF-06 & 5'GGGAATTCGG3' & 11 & 09 & 02 & 0.818 \\
\hline OPI-18 & 5'TGCCCAGCCT3' & 12 & 10 & 02 & 0.833 \\
\hline
\end{tabular}


Table 3. Similarity matrix of fifteen Zingiber officinale Roscoe landraces, collected from different areas of Eastern India generated using Jaccard's similarity co-efficient

\begin{tabular}{|c|c|c|c|c|c|c|c|c|c|c|c|c|c|c|c|}
\hline $\begin{array}{l}\text { Rows/ } \\
\text { columns }\end{array}$ & $\begin{array}{c}\text { G-05- } \\
07\end{array}$ & $\begin{array}{c}\text { PGS- } \\
08\end{array}$ & $\begin{array}{c}\mathrm{G}-23 \\
-05\end{array}$ & $\begin{array}{c}\text { G-03 } \\
-05\end{array}$ & $\begin{array}{c}\text { GCP } \\
-18\end{array}$ & $\begin{array}{c}\text { GCP } \\
-27\end{array}$ & $\begin{array}{c}\text { GCP } \\
-22\end{array}$ & $\begin{array}{c}\text { GCP } \\
-44\end{array}$ & $\begin{array}{c}\text { G-01 } \\
-07\end{array}$ & $\begin{array}{c}\text { GCP } \\
-29\end{array}$ & IG-1 & $\begin{array}{c}\text { GCP } \\
-16\end{array}$ & $\begin{array}{c}\text { GCP } \\
-05\end{array}$ & $\begin{array}{c}\text { G-04 } \\
-07\end{array}$ & $\begin{array}{c}\text { GCP } \\
-08\end{array}$ \\
\hline G-05-07 & 1.000 & & & & & & & & & & & & & & \\
\hline PGS-08 & 0.976 & 1.000 & & & & & & & & & & & & & \\
\hline G-23-05 & 0.971 & 0.978 & 1.000 & & & & & & & & & & & & \\
\hline G-03-05 & 0.949 & 0.947 & 0.952 & 1.000 & & & & & & & & & & & \\
\hline GCP-18 & 0.936 & 0.947 & 0.956 & 0.969 & 1.000 & & & & & & & & & & \\
\hline GCP-27 & 0.789 & 0.786 & 0.795 & 0.822 & 0.808 & 1.000 & & & & & & & & & \\
\hline GCP-22 & 0.751 & 0.758 & 0.767 & 0.758 & 0.744 & 0.729 & 1.000 & & & & & & & & \\
\hline GCP-44 & 0.762 & 0.773 & 0.778 & 0.769 & 0.756 & 0.736 & 0.954 & 1.000 & & & & & & & \\
\hline G-01-07 & 0.738 & 0.744 & 0.753 & 0.744 & 0.731 & 0.716 & 0.952 & 0.954 & 1.000 & & & & & & \\
\hline GCP-29 & 0.747 & 0.758 & 0.775 & 0.753 & 0.753 & 0.725 & 0.934 & 0.949 & 0.956 & 1.000 & & & & & \\
\hline IG-1 & 0.797 & 0.795 & 0.804 & 0.822 & 0.813 & 0.982 & 0.738 & 0.744 & 0.725 & 0.733 & 1.000 & & & & \\
\hline GCP-16 & 0.780 & 0.782 & 0.791 & 0.813 & 0.804 & 0.960 & 0.716 & 0.722 & 0.703 & 0.716 & 0.960 & 1.000 & & & \\
\hline GCP-05 & 0.795 & 0.797 & 0.806 & 0.828 & 0.819 & 0.980 & 0.736 & 0.742 & 0.722 & 0.731 & 0.987 & 0.958 & 1.000 & & \\
\hline G-04-07 & 0.784 & 0.786 & 0.795 & 0.822 & 0.808 & 0.989 & 0.729 & 0.736 & 0.716 & 0.725 & 0.982 & 0.960 & 0.980 & 1.000 & \\
\hline GCP-08 & 0.780 & 0.778 & 0.786 & 0.808 & 0.800 & 0.956 & 0.720 & 0.727 & 0.707 & 0.720 & 0.960 & 0.969 & 0.958 & 0.956 & 1.000 \\
\hline
\end{tabular}

Table 4. Total Antioxidant potential of fifteen landraces of Zingiber officinale.Roscoe landraces, collected from different areas of Eastern India

\begin{tabular}{|c|c|c|c|c|c|c|}
\hline $\begin{array}{c}\text { Serial } \\
\text { No }\end{array}$ & $\begin{array}{c}\text { Sample } \\
\text { Accession } \\
\text { Number }\end{array}$ & $1^{\text {st }}$ Value & $2^{\text {nd }}$ Value & $3^{\text {rd }}$ Value & $\begin{array}{c}\text { Mean Value of } \\
\text { triplicates } \\
\text { \% of DPPH } \\
\text { reduced })\end{array}$ & Standard Error \\
\hline 1 & GCP-18 & 89.47 & 89.23 & 89.27 & 89.32 & 0.074237 \\
\hline 2 & G-05-07 & 88.23 & 88.56 & 89.09 & 88.62 & 0.250488 \\
\hline 3 & G-03-05 & 88.32 & 88.53 & 87.46 & 88.10 & 0.327329 \\
\hline 4 & PGS-8 & 88.53 & 88.63 & 88.84 & 88.66 & 0.091348 \\
\hline 5 & G-23-05 & 89.29 & 89.39 & 89.23 & 89.30 & 0.046667 \\
\hline 6 & IG-1 & 84.11 & 84.36 & 84.77 & 84.74 & 0.21682 \\
\hline 7 & GCP-27 & 85.69 & 85.68 & 85.84 & 85.73 & 0.051747 \\
\hline 8 & GCP-05 & 84.34 & 85.43 & 85.97 & 85.58 & 0.479386 \\
\hline 9 & GCP-8 & 85.01 & 85.06 & 85.47 & 85.18 & 0.145717 \\
\hline 10 & G-04-07 & 85.02 & 85.17 & 85.21 & 85.13 & 0.057831 \\
\hline 11 & GCP-16 & 85.02 & 85.13 & 84.84 & 84.99 & 0.084525 \\
\hline 12 & GCP-22 & 78.31 & 78.42 & 78.58 & 78.43 & 0.078387 \\
\hline 13 & GCP-29 & 77.72 & 77.71 & 77.25 & 77.89 & 0.178357 \\
\hline 14 & G-01-07 & 76.01 & 76.09 & 76.47 & 76.19 & 0.141892 \\
\hline 15 & GCP-44 & 77.31 & 77.43 & 77.60 & 77.44 & 0.08413 \\
\hline
\end{tabular}




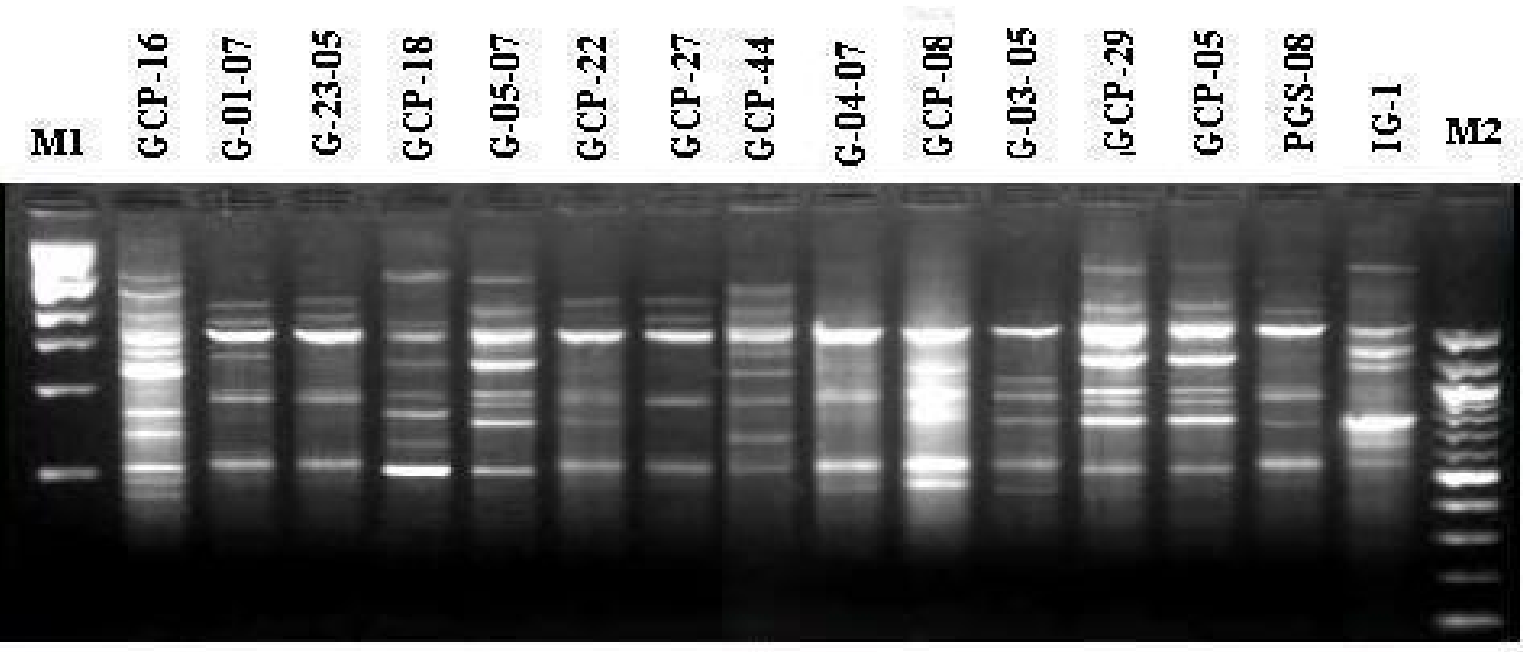

Figure 1. Representative RAPD Pattern of fifteen landraces of Zingiber officinale Roscoe, using primer OPAI-05, collected from different areas of Eastern India .M1-1Kb ladder (NEB), M2-100bp ladder (NEB)

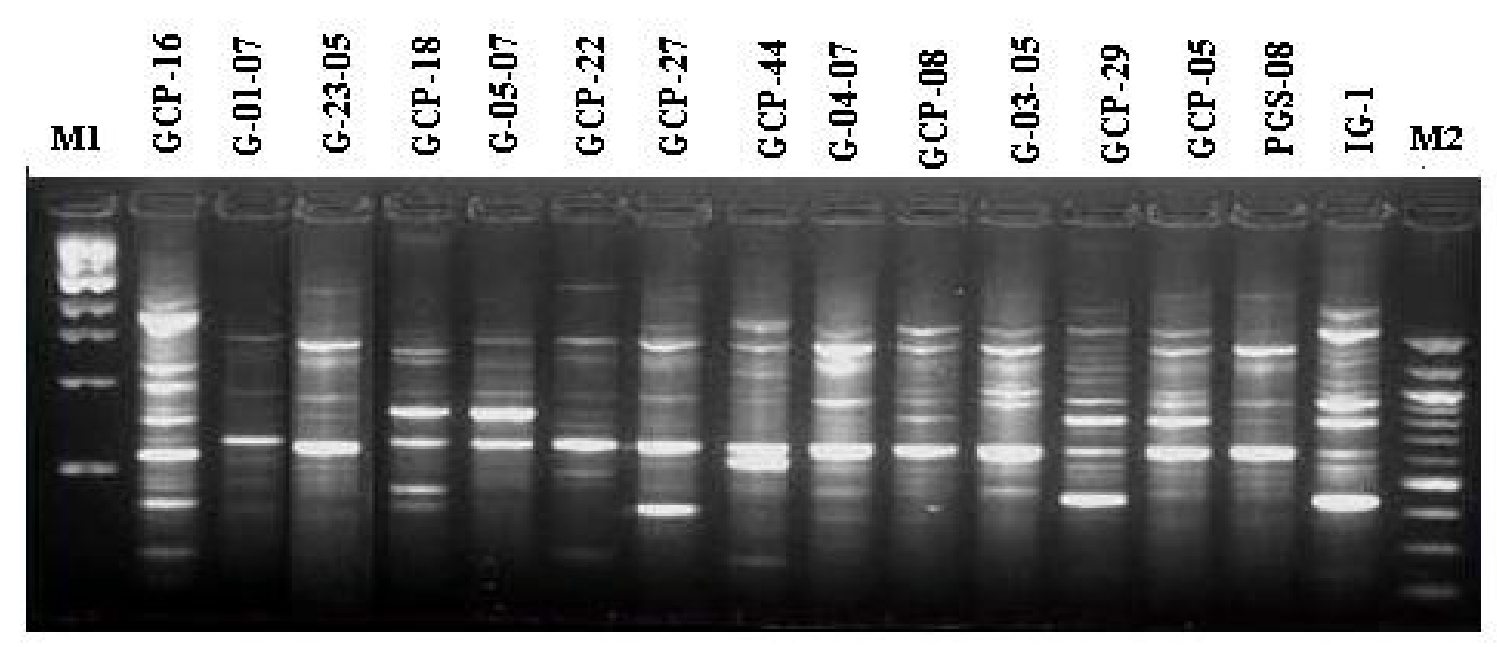

Figure 2. Representative RAPD Pattern of fifteen landraces of Zingiber officinale Roscoe, using primer OPAL-04, collected from different areas of Eastern India . M1-1Kb ladder (NEB), M2-100bp ladder (NEB) 


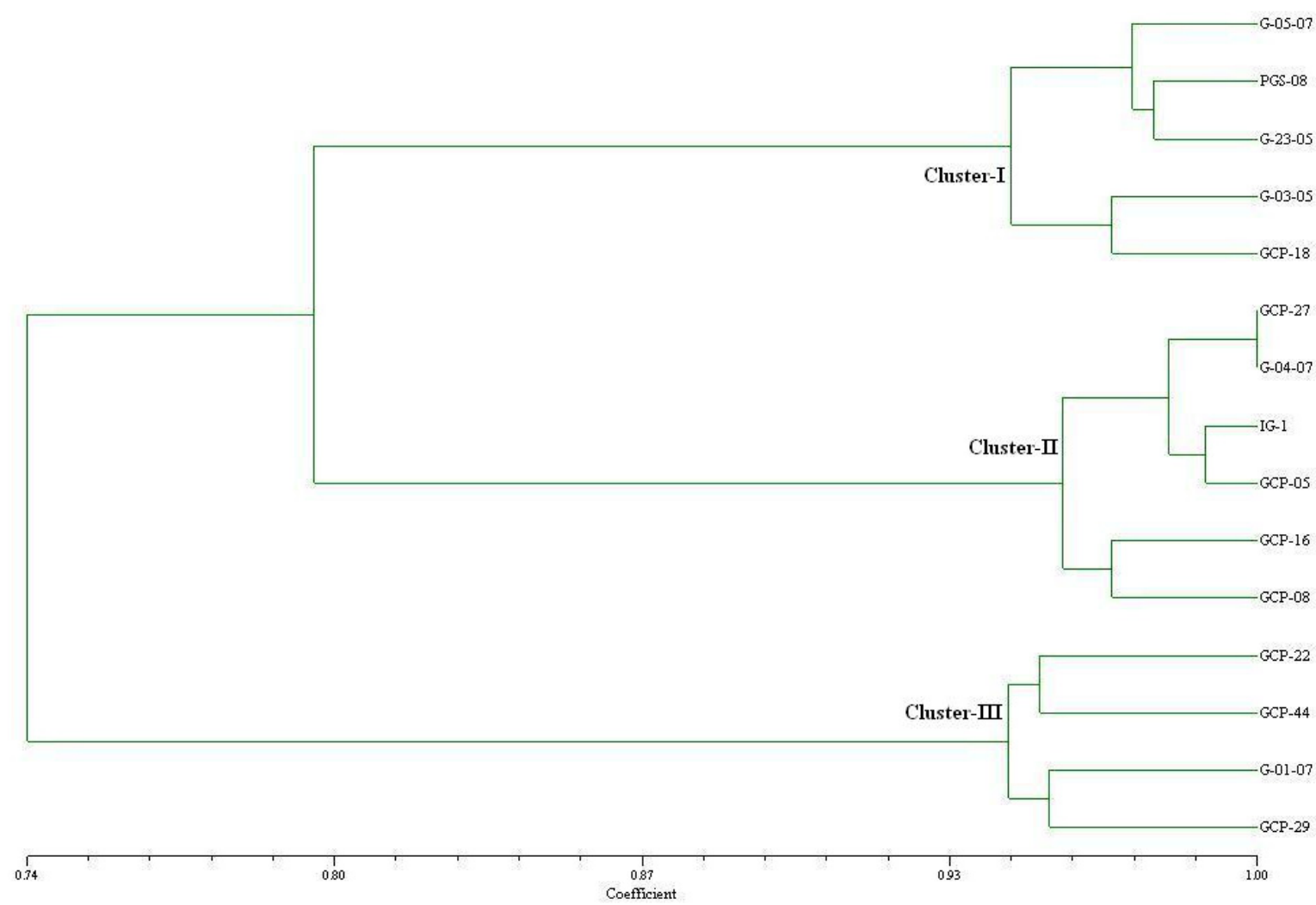

Figure 3. Cluster diagram produced by UPGMA cluster analysis after RAPD of fifteen landraces of Zingiber officinale. Roscoe, collected from different areas of Eastern India, using 16 random decamer primers, showing phylogenetic relationship among them 